\title{
Comparing SOFA scores of ICU patients in a low income national referral hospital
}

\author{
C Sendagire $^{1 *}$, D Obua $^{1}$, J Nakibuuka ${ }^{2}$, J Ejoku ${ }^{3}$, A Kwizera $^{1}$ \\ From ESICM LIVES 2015 \\ Berlin, Germany. 3-7 October 2015
}

\section{Introduction}

Sub-Saharan Africa has a significantly growing burden of critical illness on account of high prevalence of sepsis, HIV, trauma and obstetric complications. With scarce data on organ dysfunction in low income countries we analyzed the latter by comparing SOFA scores between survivors and non-survivors. We replaced the Pa02/Fi02 ratio with $\mathrm{SP} 02 / \mathrm{Fi} 02$ ratio.

\section{Objectives}

To compare SOFA scores between ICU survivors and non-survivors in Mulago National Referral Hospital general intensive care unit.

\section{Methods}

We performed a prospective observational study in Mulago general ICU on patients above 12 years. We excluded postoperative patients admitted for low risk monitoring or less than 24hours. The worst SOFA scores were calculated at admission and 48 hours, including the difference thereof. Patients were then followed up to discharge or death.

\section{Results}

135 patients were consecutively enrolled from February 2014 to January 2015, 17 were excluded. Interim analysis was done on 118 patients; the median age 34 years, 57.6\% male and the overall ICU mortality $47.5 \%$. Median survival time was 12 days with (95\% CI 6.38-17.62).

Comparing the mSOFA score means, the non-survivors vs. survivors; the initial mSOFA (7.7 vs. $5.5 ; \mathrm{p}=0.007$ ), mean mSOFA ( 8.1 vs. $4.7 ; \mathrm{p}=0.00001)$, and highest mSOFA (9.4 vs. 5.8; $\mathrm{p}=0.00001)$. We found that in survivors the delta mSOFA decreased by $2.7(1.7)$, it increased

${ }^{1}$ Makerere University College of Health Sciences, Department of Anaesthesia, Kampala, Uganda

Full list of author information is available at the end of the article by 1 (3.1) after 48hours in non-survivors. On admission, only the SOFA-RS and SOFA-CVS means were significantly different between non-survivors vs. survivors; ( 2 vs. $1 ; \mathrm{p}=0.007)$ and ( 1 vs $0 ; \mathrm{p}=0.001)$ respectively. We however found that at 48hours, non-survivors also had a significantly higher SOFA-Renal and SOFA-CNS mean scores than survivors; ( 3 vs. 2 ; $\mathrm{p}=0.0001)$ and $(2$ vs. 1 ; $\mathrm{p}=0.0001)$ respectively.

\section{Conclusions}

Non-survivors have significantly higher initial, mean, and highest SOFA scores and more number of organ dysfunctions after 48hours.

\section{Funding}

Self-funded as part of post-graduate thesis.

\section{Authors' details}

'Makerere University College of Health Sciences, Department of Anaesthesia, Kampala, Uganda. ${ }^{2}$ Mulago National Referral Hospital, Department of Medicine, Kampala, Uganda. ${ }^{3}$ Mulago National Referral Hospital, Department of Anaesthesia, Kampala, Uganda.

Published: 1 October 2015

\section{References}

1. Dunser M, Baelani WI, Ganbold L: A review and analysis of intensive care medicine in the least developed countries. Crit Care Med 2006, 34:1234-1242.

2. Ferreira LF, Bota DP, Bross A, Melot C, Vincent JL: Serial Evaluation of the SOFA Score to Predict Outcome in Critically III Patients. JAMA 2001, 286(14):1754-1758.

3. Kwizera A, Dünser M, Nakibuuka J: National intensive care unit bed capacity and ICU patient characteristics in a low income country. BMC Research Notes 2012, 5(475):1-6.

4. Pandharipande PP, Shintani AK, Hagerman HE, St Jacques PJ, Rice TW, Sanders NW, Ware LB: Derivation and validation of Sp02/Fi02 ratio to impute for $\mathrm{PaO2} / \mathrm{Fi02}$ ratio in the respiratory component of the Sequential Organ Failure Assessment score. critical Care Medicine 2009, 37(4):1317-1321.

\section{SpringerOpen $^{\odot}$}

(c) 2015 Sendagire et al.; This is an Open Access article distributed under the terms of the Creative Commons Attribution License (http://creativecommons.org/licenses/by/4.0), which permits unrestricted use, distribution, and reproduction in any medium, provided the original work is properly cited. 
doi:10.1186/2197-425X-3-S1-A337

Cite this article as: Sendagire et al:: Comparing SOFA scores of ICU

patients in a low income national referral hospital. Intensive Care

Medicine Experimental 2015 3(Suppl 1):A337.

\section{Submit your manuscript to a SpringerOpen ${ }^{\circ}$ journal and benefit from:}

- Convenient online submission

- Rigorous peer review

- Immediate publication on acceptance

- Open access: articles freely available online

- High visibility within the field

- Retaining the copyright to your article

Submit your next manuscript at $\gg$ springeropen.com 